\title{
Strategies for Improving Music Appreciation Ability of Non-music Majors
}

\author{
Huawei Zhang \\ Department of Music, Dongchang College of Liaocheng University, Shandong, China, 252000
}

Keywords: Non-music major; music appreciation ability; strategy

Abstract: As an important part of quality education, music education plays an important role, which cannot be ignored. It can not only cultivate students' elegant aesthetic taste, but also strengthen students' moral accomplishment. It can be said that both music majors and non-music majors should receive music education. Only in this way can the comprehensive development of quality and ability be realized. This paper will discuss and analyze the significance of music education for non-music majors, and formulate corresponding solutions based on the main problems in the current teaching process, in order to strengthen the actual effect of music education, so as to promote the steady improvement of non-music majors' music appreciation ability.

Music can bring people the enjoyment of beauty, relieve people's psychological pressure, and make people get a moment of peace and rest in their busy life, so it is deeply loved by people. College students are the pillars of the country. They shoulder the great mission of building socialism. They must have higher quality and ability, which puts forward more stringent requirements for higher education. In order to promote the coordinated and healthy development of College Students' body and mind and realize the goal of talent cultivation in Colleges and universities, colleges and universities should vigorously carry out music education, especially attach importance to the cultivation of music appreciation ability of non-music majors, so that they can form correct aesthetic outlook and values, and cope with difficulties and challenges in learning and life with a positive attitude, so as to create national and social needs. Modern talents.

\section{Important significance of implementing music education for non-music majors}

As we all know, the diversity of music types determines that music education has a very rich connotation. By enjoying different styles of music, students can get unprecedented audio-visual enjoyment, deeply immersed in the artistic conception created by music, resulting in emotional changes such as happiness, anger, sadness and employment. At this time, studentships on teachers will be more acceptable, which will help the smooth development of teaching activities. Exhibition. Specifically, the significance of music education for non-music majors lies in the following aspects:

\subsection{Integration of music education and aesthetic education}

Music education is an important carrier of aesthetic education and emotional education. Music 
contains rich thoughts and feelings. In the process of enjoying music, maximizing emotions can arouse interdenominational resonance and enable students to think deeply. It is very helpful for enlightening students' thinking and developing intelligence. At the same time, in music education, aesthetic education is integrated, music knowledge is imparted with the help of music-specific language, music connotation is understood, supercontinent ability is exercised, so that students gradually change from appreciating and discovering beauty to pursuing and creating beauty. Students' aesthetic literacy has been greatly improved, and this state will continue to science and culture knowledge. In learning, keeping high morale and vigorous enthusiasm, in this case, higher education will achieve twice the result with half the effort.

\subsection{The integration of music education and moral education}

It is of vital importance to infiltrate moral education into music education. In the new era, the talents needed by the state and society should not only possess rich professional knowledge, but also have a high sense of social responsibility and moral accomplishment. They can actively perform their duties and contribute the greatest wisdom and strength to socialist construction. For non-music majors, their learning tasks are heavy, often in a tense and anxious mood, coupled with the increasingly severe employment situation, resulting in increasing psychological pressure on College students, which is easy to produce a variety of mental health problems. Music can make college students relax physically and mentally and eliminate their negative emotions. Then college students will have no worries when they study. They will devote themselves wholeheartedly to it, and their learning efficiency and quality will be guaranteed.In addition, music is the product of culture, the crystallization of wisdom, and an effective way to disseminate traditional culture. It enables students to remember history and never forget responsibility. Music is also closely related to other disciplines. Through music appreciation, the cultural differences between different countries and regions are conveyed to students. Popularizing patriotic education and humanistic education and strengthening misunderstanding of professional knowledge are conducive to deepening students' thinking, shaping studentship personality and stimulating students' patriotism. Students can also learn from music how to get along with others, how to play a good role in society and family, significantly enhance studentship adaptability, and show the educational function of music education.

\section{An analysis of the current situation of music education for non-music majors}

Table 1. The Current Situation of Music Education for Non-Music Majors

\begin{tabular}{|c|c|}
\hline Education status & standard deviation \\
\hline Teaching Object Problem & 2.7357 \\
\hline Teaching Content Questions & 3.3241 \\
\hline Teaching methods & 3.1673 \\
\hline
\end{tabular}

As shown in Table 1, the present situation of education for non-music majors will be analyzed in detail below.

\subsection{Teaching object problem}

Generally speaking, the main object of music education for non-music majors is non-music majors. Their music knowledge is relatively scarce and their ability to appreciate music is not high. It is often difficult to accurately grasp music emotions, which has brought a lot of obstacles to the development of music education. Moreover, these denuclearizing attitude is not correct enough. 
They think that music appreciation course has little connection with this major course, and they don't need to invest too much time and energy to study. Therefore, when teachers teach, they often find that students slip away and their attention is not focused. Classroom order is very chaotic, and other students are difficult to calmly enjoy music, which leads to music education and teaching for non-music majors. Learning goals are hard to achieve.

\subsection{Teaching content questions}

From the current situation of music education for non-music majors in China, there is no unification in teaching materials, the textbooks used in Colleges and universities are more arbitrary, and the teaching objectives are not clear enough. All these restrict the non-music appreciation of music and the study of music knowledge. As an important reference for music education, the influence of textbooks on teaching effect can not be underestimated. Only by ensuring the Scientology and rationality of teaching content, truly satisfying the physical and mental development needs of non-music majors, and connecting with their professional knowledge, can they arouse uninteresting in learning and keep their thinking active. At this time, non-music majors' music can be aroused. Literacy will also be well developed.

\subsection{Teaching methods}

Teachers play an important role in music education for non-music majors. If teachers follow the old ways and do not know how to change, they will lead to a dull classroom atmosphere and greatly dispel enthusiastically for learning. Some teachers have a biased understanding of music education for non-music majors. The difficulty of teaching design is not in line with studentship level. It has strong specialty, profound theoretical knowledge and little interaction with students, which is not conducive to stimulating students' enthusiasm for music learning. Some teachers explain the background, composition and style of music creation too carefully. They play a piece of music over and over again, which leads to unaesthetic fatigue and lack of interest in music appreciation.

\section{Effective measures to improve music appreciation ability of non-music major college students}

Through the analysis above, we can see that there are many problems in music education of non-music majors that need to be improved urgently. It is necessary for colleges and universities to actively implement the reform of music education and teaching, formulate scientific and reasonable teaching objectives, teaching contents, teaching methods, and organize diversified teaching activities in order to mobilize the enthusiasm and initiative of non-music majors to appreciate music, so as to promote it. Music education has been carried out steadily and orderly.

\subsection{Setting reasonable teaching objectives}

In order to ensure the effectiveness of music education for non-music majors, first of all, we should define the teaching objectives, which is the necessary prerequisite for promoting the orderly development of all aspects of music education for non-music majors. Music education for non-music majors should not be compared with professional music education. Besides imparting studentship knowledge, it should also cultivate students' aesthetic interest, artistic accomplishment, music appreciation ability, ideological and moral quality, and the difficulty of knowledge should not be too great, so as to avoid negative impact on denuclearizing mood. Teachers should refine the teaching objectives and decompose them into phased ones. In order to understand the shortcomings 
of current teaching, teachers should regularly evaluate the teaching effect with the goal as the guide in the implementation of music education, and then dynamically adjust the teaching plan to ensure that the teaching objectives of music education are gradually achieved. Studentship appreciation ability will also be long-term and systematic. Improvement in training.

\subsection{The teaching content of design science}

Music education is not only teaching and learning, but also requires close communication and cooperation between teachers and students. Teachers should not restrict studentship too much and stifle students' nature of advocating freedom. Instead, they should combine the psychological characteristics of non-music majors to provide students with opportunities to show themselves, so that they can play their strengths and enjoy the music in the ocean. The infinite charm will attract sentimentalization, win students' favor and support, and non-music musicological education will be more effective. Usually, college students learn music courses from their love for music. They hope to cultivate their sentiment, sublimate their soul and cultivate their comprehensive ability in music. However, in the complicated music curriculum system, college students gradually lose interest in music, which is contrary to the expected teaching objectives. In order to change this situation, teachers should improve the teaching content of music education, delete those too profound knowledge of music theory, and use questionnaire survey to understand psychological needs, design the teaching form that students like, so as to arouse students' desire for music appreciation and deepen misunderstanding of music.

\subsection{Adopting modern teaching technology}

Under the background of the information age, the traditional educational ideas and methods can no longer meet the needs of the development of higher education. In view of the diversification and rationalization of college studentships, music education for non-music majors should also be innovative, bringing more rich learning experience and sensory stimulation to students, and promoting them to enjoy the fun of music. In music education for non-music majors, it is not advisable to stick to the fixed mode, such as repeating music works and letting students express their feelings. Teachers should grasp studentships from the perspective of students and try their best to meet all their reasonable needs.

The application of modern acoustic imaging technology is undoubtedly a breakthrough in the reform of music education. Combining sound, light and image organically, students will enter the music atmosphere more quickly, and their ability to perceive music emotions will be enhanced. Students will also have a sense of immersion while enjoying music. Music is no longer an empty sound for students. It is a colorful and emotional thing, so students get a more comprehensive and profound aesthetic experience.

\subsection{Develop diversified extracurricular activities}

Because it is difficult for non-music majors to touch elegant music in peacetime, they can only receive professional music education in a short classroom time. In order to extend the position of music education and improve the effect of education, we can organize some extracurricular activities so that students can also get the edification of music in their spare time. The more common forms of extracurricular activities are as follows: 


\section{Hold after-school concert halls}

\section{organize music salons}

Figure 1. Diversified extracurricular activities

First, hold after-school concert halls. The use of school libraries, multimedia classrooms and other places to organize students to regularly or irregularly attend after-school concert halls to appreciate music, increase the number and quality of students to appreciate music, and promote their level of music appreciation.

Second, organize music salons. Organize non-music majors, set up music appreciation salon and hold music appreciation Symposium. Through discussion and communication, we can deepen college misunderstanding of music and enhance their ability of appreciating music and aesthetic appreciation.

Third, organize on-site appreciation. Combining with the arrangement of music courses, college students are organized to go to professional orchestras for practical investigation and on-the-spot music rehearsal. Professional musicians are invited to introduce the composition of Symphony orchestras, the performance styles and characteristics of various instruments, so that college students can understand music in person and enhance their perception of music.

\section{Conclusion}

The improvement of music appreciation ability of non-music majors is not achieved overnight. It needs to carry out music education in a planned and step-by-step way. According to semiprofessional characteristics and psychological needs, scientific and rigorous teaching content should be designed, appropriate teaching methods should be selected. At the same time, various extracurricular activities should be organized during students' rest to promote communication and communication among students so as to enable students to think. The collision with emotion produces higher aesthetic interest and appreciation ability, which promotes the sustainable development of music education for non-music majors.

\section{References}

[1] Wang Ciao. On How to Improve College Studentship Appreciation Ability [J]. Journal of Children University (Chinese Philosophy and Social Sciences Edition), 2015 (12).

[2] Deng Langley. Discussions on music appreciation courses in general colleges and universities [J].

[3] Li Jillian. On the cultivation of comprehensive ability in extracurricular art activities in Colleges and universities $[\mathrm{J}] .2015 .5$.

[4] Wang Changing. On Music Aesthetic Education in Universities [J]. Journal of Shanghai Normal University, August 2015.

[5] Chaotic. Reflections on the orientation and reform of university public music education [J]. 2015.5. 